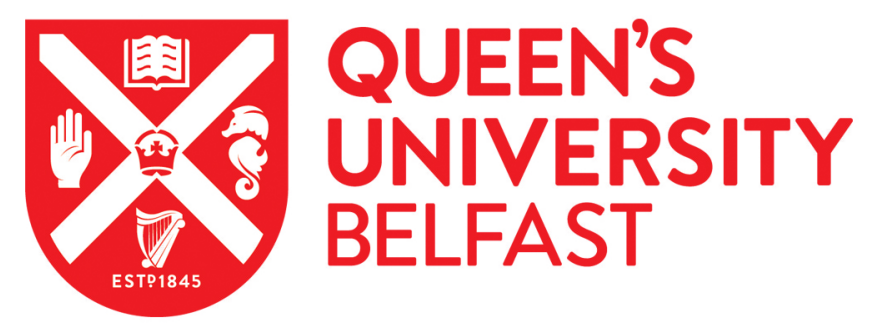

\title{
Austerity common sense and contested understandings of the austerity measures within a leadership of a professional association of social workers
}

Pentaraki, M. (2018). Austerity common sense and contested understandings of the austerity measures within a leadership of a professional association of social workers. European Journal of Social Work, 22(6), 1-12. https://doi.org/10.1080/13691457.2018.1435507

Published in:

European Journal of Social Work

Document Version:

Peer reviewed version

Queen's University Belfast - Research Portal:

Link to publication record in Queen's University Belfast Research Portal

Publisher rights

() 2018 Informa UK Limited, trading as Taylor \& Francis Group.

This work is made available online in accordance with the publisher's policies. Please refer to any applicable terms of use of the publisher.

\section{General rights}

Copyright for the publications made accessible via the Queen's University Belfast Research Portal is retained by the author(s) and / or other copyright owners and it is a condition of accessing these publications that users recognise and abide by the legal requirements associated with these rights.

\section{Take down policy}

The Research Portal is Queen's institutional repository that provides access to Queen's research output. Every effort has been made to ensure that content in the Research Portal does not infringe any person's rights, or applicable UK laws. If you discover content in the

Research Portal that you believe breaches copyright or violates any law, please contact openaccess@qub.ac.uk. 


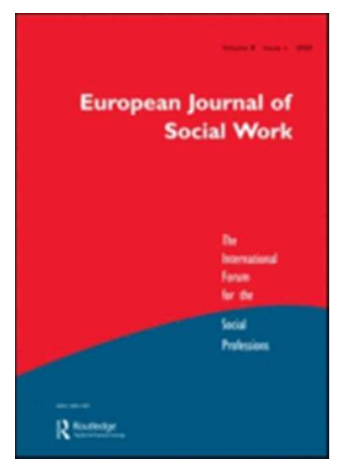

\section{Austerity common sense and contested understandings of the austerity measures within the leadership of the Professional Association of Social Workers in Greece.}

\begin{tabular}{|r|l|}
\hline Journal: & The European Journal of Social Work \\
\hline Manuscript ID & CESW-2016-0076.R1 \\
\hline Manuscript Type: & Original Article \\
\hline Keywords: & $\begin{array}{l}\text { social spending cuts, professional associaltions of social work, Gramsci, } \\
\text { critical social work tradition, neoliberalism, austerity }\end{array}$ \\
\hline \multicolumn{2}{|l}{} \\
\hline
\end{tabular}

SCHOLARONE"

Manuscripts 


\begin{abstract}
This paper introduces a preliminary conceptualisation of "austerity common sense" in order to understand why austerity policies, despite the social harm they cause, have support not only from the economic and political establishment but also from the wider population including members of the social work profession. Building on the Gramscian concept of common sense, 'austerity common sense' refers to the set of beliefs circulated by the ruling elite and adopted by members of the leadership of the Professional Association of Social Workers (SKLE), as well as others within Greece and the European Union, to understand austerity policies. Through this framing, austerity measures are largely accepted as inevitable rather than challengeable.

The paper maintains that the concept of austerity common sense provides an analytical framework for understanding the acceptance of austerity measures in Greece and elsewhere, since similar 'austerity common sense' framing is encountered in many countries. Furthermore, it is maintained that the concept of "austerity common sense" can facilitate the interrogation of the socio-economic construction of ideas and phrases. This is an important process with which the social work profession needs to engage.
\end{abstract}

\title{
Keywords
}

Social spending cuts, austerity, professional associations of social work, Gramsci, neoliberalism, critical social work

\section{Introduction}


Austerity measures have been the predominant policy response by the majority of governments worldwide which have been affected by the last financial crisis (Dymski, 2013). They have emerged as a default policy approach in mainstream economics (Dymski, 2013), despite widespread evidence of the immense social harm they bring (Author's own 2016) and of their incapacity to address the crisis in a socially just way. This default approach is promoted by the economic establishment which benefits substantially as it increases its share of a country's wealth (Dorling, 2014) and has considerable public support (Schui, 2014). Scholars from the critical tradition of social work (Author's own, 2013; Ioakimidis \& Teloni, 2013) have hoped that the imposition of austerity measures and the resultant social spending cuts might have united the social work profession in an unconditional resistance to all austerity measures, based on a structural understanding of the causes of austerity. However, this appears not to have happened (Author's own, 2015). The literature to date suggests that a contested understanding of the causes of austerity measures exists both within the general public (Mikus, 2014; Schui, 2014) and the social work profession (Author's own). In Greece, this contested understanding is centred on a collective blame framing for the imposition of austerity measures and the Higher Greek Public Debt Crisis (HGPDC) (Author's own). This paper seeks to develop this theme which was initially identified in a case study conducted by the author with the leadership of the Professional Association of Social Workers (Greek transliteration- SKLE) in 2011, during the first phase of austerity measures. Furthermore, the paper builds on the Gramsian concept of common sense (Gramsci, 1971) to introduce the preliminary conceptualisation of the concept of "austerity common sense" as a useful analytical framework within which to understand the acceptance of austerity measures by the wider public. Building on the Gramscian concept of common sense, austerity common sense refers to the set of beliefs circulated by the ruling elite and adopted by some members of the leadership of the SKLE, as well as others within Greece and the European Union, to understand austerity policies. 
Through this framing, austerity measures are widely accepted as inevitable rather than challengeable.

Before the paper turns to the presentation of the study and the concept of austerity common sense, it briefly introduces the context of the austerity policy and the salient Gramscian theoretical conceptualisation.

\section{Context of the austerity policy response}

The austerity policy response is becoming a permanent institutional feature of governments in the European Union. This permanence is achieved through structural reforms that aim to change the institutional framework governing welfare issues, labour relations, and other aspects of the economy (Hermann, 2014a). Leading scholars argue that under the pretext of managing the public debt and responding to the crisis the entrenchment of neoliberalism is achieved (Harvey, 2005; Stiglitz, 2002). This public debt has been caused not by social spending, but by the uncontrollable financial speculation of the finance/banking sector, whose bank losses were skillfully transferred by the establishment to national governments through bank bailouts and then to society at large (Author's own; Dymsky, 2013). This skillful transformation of bank losses to public debt led to crisis driven structural reforms supposedly aimed at addressing the public debt. These though challenge the core of the European Social Model(s) so that “ Cuts in social benefits and pension payments, the promotion of atypical employment and the erosion of employment protection, the decentralisation of collective bargaining and the weakening of bargaining structures and interest representation reverse the decommodifying effect build in the European Social Model(s)" (Hermann, 2014b, p. 14). From 2010 onwards, during the second phase of the crisis, this process accelerated when a number of European governments turned from deficit-spending to austerity and welfare state spending became a major target of budget consolidation (European Commission, 
2013a). By 2011, this process had resulted in a decline in social expenditure in a number of European countries (European Commission, 2013b). Such cuts in social spending, together with the lack of growth, have fuelled poverty and social exclusion. Thus, in 2012, one in four Europeans lived on less than $60 \%$ of median national income. This number had increased by a staggering 6.7 million since the start of the crisis (European Union, 2014, p.19).

One of the countries affected most harshly by the implementation of austerity measures is Greece. The neoliberal structural reforms imposed on Greece by the European Union, European Central Bank and the International Monetary Fund (TROICA) have resulted in social spending cuts ranging from $20 \%$ to $62 \%$, massive unemployment (almost 30\% on average and 65\% for young women), the privatisation of public services and the underfunding and understaffing of the welfare state (Karamesini, 2014). These have led to immense social harm and the human rights violation of the people in Greece (Salomon, 2015).

In order to legitimise these policies as 'unavoidable' and stemming from factors specific to the Greek context, a number of unfounded assertions have been widely circulated by politicians of the establishment and the mass media across Europe (Author's own; Mylonas, 2014). Among them have been claims labelling Greece as: 'The Cheats of the European Family' (Focus, 2010), a country with one of the largest numbers of public servants (ENET, 2010), one of the most generous welfare states (Channel 4, 2011), the most wasteful state (Landon, 2011) and home to the laziest people (Gathmann $\&$ Medick, 2011). Furthremore, one of the most frequently used unfounded assertions circulated is the collective responsibility of all Greek citizens for the misappropriation of public resources (see, for example, NEA, 2010) that supposedly led to the spiralling of the public debt crisis. In the context of the economic crisis, the phrase 'We ate them all together' was first coined during the first phase of imposed austerity measures (in 2010) 
by the then Deputy Prime Minister, Theodoros Pagkalos (see, for example, NEA, 2010). Subsequently, 'We ate them all together' has been employed by the mainstream political and economic elite to describe a sense of collective blame for the sustained misuse of public resources that purposively led to the spiralling public debt.

This paper seeks to examine this collective blaming framing through the phrase "We ate them all together" as discussed within the leadership of SKLE. This is the first paper to address the existence of collective blaming within the social work profession and to raise the importance of being able to interrogate such framings. Moreover, by utilising Gramsci's thought, which is briefly presented in the following section, the paper centres in introducing a preliminary conceptualisation of austerity common sense.

Gramscian theoretical concepts (This has become a distinct section per reviewers' comments)

Gramsci’s thought has been utilised by many authors (Garrett, 2008, 2009, 2017; Author's own, 2013) in order to advance an understanding of present socio-economic conditions. It has been argued that his theorisation can inform social work scholarly work and understanding (Garrett, 2008, 2009, 2017; McKinnon, 2009; Singh \& Cowden, 2009; Author's own). Hegemony and common sense are two of his theoretical concepts that inform the present work. In The Prison Notebooks (1971), Gramsci argues that existing power relations in society are reinforced through hegemony. In the use of the term 'hegemony', Gramsci describes how the ruling class establishes and maintains its control. Hegemony entails the process through which ruling class ideas are accepted as common sense (which should not be confused with the notion of being practical).

Common sense is "a form of 'everyday thinking' which offers [...] frameworks of meaning with which to make sense of the world [through the eyes and interests of the ruling class]. It is a form of popular, easily-available knowledge which [...] does not 
depend on deep thought. It works intuitively, [...] giving the illusion of arising directly from experience" (Hall and O’Shea 2013, p.9). According to Gramsci, common sense encompasses the "diffuse, uncoordinated features of a general form of thought common to a particular period and a particular common environment" (Gramsci, 1971, p. 330). For Gramsci, language is central to establishing and understanding the organisation of consent since language is both the medium though which ideas are expressed and is central to determining and reflecting social arrangements in a particular environment and time (Ives, 2004)

An example of this is the contemporary austerity environment and the collective blaming framing for the deficit that the ruling class uses to justify social spending cuts. However, at the same time common sense comprises "a healthy nucleus of good sense" which he argues, "deserves to be made more unitary and coherent" (Gramsci, 1971, p.328). This good sense, which in this research reflects the challenging of the collective blaming framing, also suggests the possibility of challenging austerity measures to form the basis for a Gramscian counter hegemonic response to austerity. For Gramsci, when the ideas of the ruling class become self-evident, hegemony has been achieved-even though 'selfevident' common sense becomes a site of ideological contestation (Gramsci, 1971).

\section{The study (I elaborated on this paragraph per reviewers' comments)}

The research reported in this paper is a component of a larger explorative study that sought to examine the response of the leadership of SKLE to the economic crisis and the factors that might influence this response (author's own, 2015). The study included two focus groups of 87 and 37 minutes duration respectively and three in-depth interviews with members of the leadership of SKLE (nine out of the 11 members, seven women and two men) during the first phase of the imposition of the austerity measures in 2010-2011. As suggested by the president of SKLE, the focus group discussions were arranged 
immediately prior to executive meetings of SKLE. This was acceptable to the researcher since the SKLE committee constructs a collective voice through the meetings. Thus, in a sense, the focus group can be thought to approximate the natural space of interaction (Kamberelis \& Dimitriadis, 2013). The members of the executive committee of SKLE were all committed working professionals who were elected by the general membership of SKLE and volunteer their time to the professional association in order to advance the interests of the profession. Their experience was wide -ranging, from two to 20 years' experience in SKLE as an elected committee member and between one to 26 years' working in the social work profession. Ethics approval was granted by the relevant university committee according to usual processes. At the start of the first focus group the research project was explained to the participants and each participant signed an informed consent form. It was made clear that this was a study about SKLE's response and understanding of the economic crisis, but that each person's contribution would be anonymised. Thematic analysis (Braun \& Clarke, 2006) was used to analyze the focus group participants' discussion surrounding the collective blaming theme identified in a previous published research (author's own). The themes analysed emerged out of the discussion, i.e. they were participant led rather than researcher led. (For a detailed discussion of the characteristics of the participants and the overall methodology of the component of the research where the collective blaming theme emerged please see Author's own, 2015).

\section{Findings}

The members of the executive committee did not share the same understanding of the causes of the Greek crisis. The division centred on the theme 'We ate them all together' or the less literal translation 'We are all to blame'. This theme emerged organically 
during a discussion about the origins of the Greek Public Debt Crisis (GPDC) and the austerity measures. The theme was introduced first by a high-ranking participant to reflect a collective blame understanding of the austerity measures. The use of the verb 'eat' is used to denote the unlawful use and consumption of resources as first used by Pagkalos, the deputy leader of the Greek Parliament, in 2010. However, the participants disagreed over the collective blame framing of the crisis perpetuated by the politicians and the mass media of the establishment.

The members who repeated this dominant understanding also engaged in negative attributions towards other public sector workers and seemed to blame the value system, rather than the institutional structures, for the GPDC. Broadly, one third of the members engaged in attribution of collective blame, one third challenged that attribution, and the rest did not take sides. Among the members who attributed collective blame were the highest-ranking as well as the ones who clearly identified with PASOK, the party which introduced the TROICA's austerity measures to Greece (originally a social democratic party turned neoliberal since 1987). However, the rest of the participants did not offer information about their party affiliation.

\section{'We ate them all together?'}

The contentious theme 'We ate them all together' was raised by some members in order to suggest collective responsibility for the exacerbation of the GPDC. When one high ranking member dubbed Pagkalos "essentially right" in his collective blame assessment, another agreed outright. Although three others did not share the same opinion, they were summarily side lined from the conversation. Those who subscribed to the 'We ate them all together' explanation, responded to the objection that politicians perhaps bore a greater share of the blame, with one member asserting, "We ate them all together. Just someone had a bigger belly". 
Member 1: What Pagkalos said, 'Ola mazi ta fagame' ('We ate them all together'), in its essence was right.

Member 2: Yes, he was right.

Member 1: Everyone tried in every possible way to take advantage of everything.

Members 3 \& 4: We disagree.

Member 1: Continued to discuss different examples, such as making a personal phone call from the office as an example of collective blaming (Author'sown). Some members agreed and others disagreed with the examples, as the following comments reflect:

Member 5: This is not the same degree of responsibility.

Member 1: It is very important what he said, 'We ate them all together'. Just someone had a bigger belly ...

Member 5: But the political leaders have not one, but ten times more responsibility

Member 1: ... Everyone is looking to find ways to grab what $\mathrm{s} / \mathrm{he}$ can.

Member 5: Yes, but we have to see everyone's responsibility ... My director has more responsibilities if he does not implement the regulations [than me, the supervisor]. 
Member 3: Who had the responsibility of placing people in important positions ... that took advantage ... Is it me or is it you? [...] I am not taking responsibility as this lies with those who brought the country to this point. Either they were called New Democracy ${ }^{4}$ or these ones [PASOK] ...

Member 6: ... We cannot equate things.

Member 1: When we paid for flower arrangements [for our conferences] ...we contributed in everything. And in our culture what he [Pagkalos] said is dominant ...'We all ate them together', nevertheless.

Member 7: Nevertheless, 'we ate them together' [ironically].

Member 1: Oh, come on you guys, 'We ate them together'. Member 5: I said something else ...

Member 1: 'We ate them together' takes us somewhere else.

Member 7: I do not disagree with 'We all ate them together', but there was generally a sense that 'We ate them together indiscriminately'.

Member 3: This came out for those who were not reliable.

This is part of the dialogue which occupied the largest part of the focus group discussion and clearly reflects two different arguments forming a contested understanding 
of the crisis. First, some members argued, amongst other things, that "Everyone tried in every possible way to take advantage of everything", "Everyone is looking to find ways to grab what s/he can", "[a]nd in our culture what he [Pagkalos] said is dominant ...We ate them all together [We are all to blame]."

These members advocating these statements seem to endorse the dominant explanation provided by the establishment politicians (in this case Deputy Prime Minister Pagkalos) and the mass media, that everyone in Greece is responsible for the crisis; that blame resides with individuals and national cultural attitudes and not with systemic factors (Author's own, 2013; 2015; Mylonas, 2012, 2014).

Secondly, there are members who challenge this dominant understanding. The members who contested this stated arguing clearly that they would not "undertake the responsibility that lies" with the policies of the parties of the establishment [New Democracy and PASOK].

\title{
Deserving and undeserving public sector workers
}

The division between so-called deserving and undeserving public sector workers is another concept that emerged from the members who endorse the collective blame explanation and are themselves public sector workers. Those who do not subscribe to the dominant discourse challenged this interpretation. The following dialogue reflects this:

\begin{abstract}
Member 1: ... For us who were making $€ 1300$ a month it is bad that our wages were cut, but our colleagues in the Ministry of Economics who made double the money? For all these years they really should not have been earning those kinds of salaries.
\end{abstract}

Member 8: ... [B]ut I should not be held responsible for that. 
This part of the discussion blames some so called privileged high salaried undeserving public workers for the necessity of horizontal salary decreases. It clearly divides public sector workers between deserving and undeserving. This theme suggests a divide-andconquer strategy that has been used to undermine any opposition to the dominant social order. This was clearly identified by a participant during the focus group, when she stated that: "This is what (the government) attempts to do, to bring the working class into conflict".

Categories of deserving and undeserving public sector workers are constructed not only according to differences in salary, but also according to value systems. The following part of the dialogue centres on value issues:

Member 1: ... For all these years I have not taken bribes, though they've called me an idiot [...] I did not snitch on my colleague who left work for 5 hours; I covered him. I wasn't going to be a rat. But he was stealing time from both the citizens and the state.

Two members: Yes, we agree [jointly].

Member 7: [He was stealing] from the unemployed citizens who could have held his job, too.

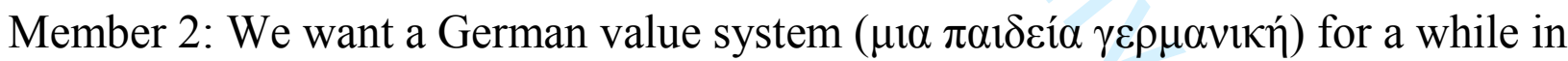
order to understand what we have. 
Nevertheless, the dominant theme continues as some members attempt to construct themselves as 'good' public sector workers, in opposition to their 'bad' counterparts.

\section{Discussion}

In this article, the theme of collective responsibility, as reflected through the phrase "We ate them all together" that emerged as both an explanation and a source of contention for the SKLE Board, is situated within a critical social theory approach informed by Gramsci. The paper argues that it needs to be contextualised within the political and economic elite's ideas and discourses circulated both in Greece and elsewhere. This contextualisation is important as ideas can be influenced by the wider dominant political processes and influence social arrangements (Garrett, 2017; Beland \& Cox, 2011; Ives, 2004; Gramsci, 1971). It is through the endorsement of elite's ideas as self-evident that hegemony is achieved (Gramsci, 1971).

The phrase 'We ate them all together' can be approached as an expression of the political and economic elite's attempts to relocate the blame from structural factors to individual factors, in order to build consent for the austerity measures imposed. In Gramscian terms, this may be explained as ruling class attempts to enforce its hegemony by presenting its ideas as common sense (Gramsci, 1971).

In the Greek context, it may be argued that Pagkalos's phrase, 'We are all to blame', was intended to frame the Greek Public Debt Crisis as being caused by all the people of Greece, including public servants. This phrase was repeated not only by domestic politicians (ENET, 2010), but also by politicians from other European Union countries, such as Chancellor Angela Merkel of Germany (Gathmann \& Medick, 2011), resulting in the wholesale victimisation of Greek citizens as bearers of an unacceptable and unjustifiable level of collective responsibility. This attempt to shift blame from structural factors to supposedly individual, country-specific factors, is undertaken to engineer 
consent for the harsh austerity policies the country now faces. This framing implies that Greeks should endure the austerity measures because the crisis is largely their own fault. Moreover, this framing draws attention away from the fact that successive governments of PASOK and New Democracy have ruled the country from 1974 to January 2015. Although this imposition of collective guilt has been manufactured by politicians of the establishment and perpetuated by corporate media, clearly not everyone has accepted it. The discussion yielded a clear line of division, with the side arguing for collective blame framing being the most vocal. According to a Gramscian analysis, the members who disagree with the austerity common sense framing are the ones reflecting good sense, thereby suggesting that we are not all passive recipients of meaning.

Utilising the Gramscian concept of common sense (Gramsci, 1971), which refers to the adoption of the ruling elite's beliefs by the working class and explains why the working class consents to the agenda of the elite, these phrases maybe called 'austerity common sense'. They are austerity common sense because they both reflect and legitimate the austerity agenda of the ruling class that emanates from the neoliberal agenda and are a category of the common sense of neoliberalism (Hall \& O'Shea, 2013). I use the description austerity as an adjective in order to acknowledge the political context from which it emerged and which it aims to legitimise. By deploying these phrases, the ruling economic and political elite seeks to influence the perception of the people. They aim to hide the facts by presenting their opinion as self evident (Gramsci, 1971). Their dominant theme is that there is no alternative and austerity measures are somehow self-inflicted and as such should not be challenged because somehow we are all to blame. These ideologically laden phrases reflect, as Zizek (2009:17) argues, attempts by the ruling class to impose an 'ideological interpretation or story' and forge an acceptable 'narrative' during this long and deepening crisis for capitalism. 


\section{Implications of the endorsement of the dominant discourse}

The SKLE members who attribute collective responsibility for the economic crisis to all Greek citizens also seem to promote the division of public sector workers into 'deserving' and 'undeserving' categories. According to the examples given, categories of deserving and undeserving public sector workers seem to be constructed according to differences in salary and to value systems. It is suggested by some members that public sector workers making more than 1300 euros per month justifiably facing cut backs unlike social workers who make under 1300 euros. Thus, a tacit acceptance is given to job losses in the public sector, perhaps owing to the mistrust embedded in societies characterised by economic inequalities.

There is a growing body of academic research typified by Picket and Wilkinson (2009), which suggests that economic inequality reduces trust between individuals and diminishes social cohesion and solidarity (Lorenz, 2005). While this theory may pertain to the case of the Greek social workers, perhaps the participants are just expressing the dominant narrative that public sector workers are lazy, overpaid and responsible for the necessity of the cuts. It seems to correspond to another austerity common sense, the one of the inadequate public sector worker used to legitimise public sector cuts (Mikos, 2015). As Harvey (2005) argues, firing public sector workers and/or decreasing their wages is an essential element of the neoliberal restructuring underway and a key strategy against state intervention.

The participants also attribute the causes of the economic crisis to the national value system which is reflected in Member 2's statement that "We want a German value system ( $\mu 1 \alpha \pi \alpha 1 \delta \varepsilon i ́ \alpha \gamma \varepsilon \rho \mu \alpha v \imath \kappa \eta$ ) for a while". The German value system is implied to be superior to the Greek value system. This statement reflects tacit acceptance of so-called 'German values' and ignores the fact that the largest misappropriation/stealing of public funds in 
Greece by members of the German and Greek economic elites involved the German company Siemens (Spiegel, 2009). Lastly, they appear to accept the austerity measures as unfair but inevitable and see themselves as the loci of change. Overall, these themes deflect attention from the structural causes of the crisis by focusing attention on individual actors and their value systems. These can be approached as an ideological expression of the ruling elite's world-view, constituting elements of austerity common sense.

\section{Strategies of change: Self as the loci of change and acceptance of the austerity measures}

If the contested concept 'We ate them all together' provides a framework for understanding SKLE's leadership perception of the economic crisis, the question that follows is how that perception may shape their strategy as a professional body. It comes as no surprise that if one blames the attitudes of Greek people, including the attitudes of the public sector workers, then the locus of change is not structural but attitude-based. Member 2's statement in the preceding excerpt implies that existing attitudes need to be reshaped along German lines. This statement clearly places the attitudes as the loci of change. Changing oneself and one's own values is easier than achieving structural change. There is an observable tacit acceptance of the austerity measures in the above comments which might lead to an acceptance of the "There is no Alternative" (TINA) neoliberal dominant discourse (Harvey, 2005). The endorsement of the dominant discourse of collective responsibility leads to a sense of complicity towards the austerity measures. In turn, the acceptance of collective guilt, breeds an acceptance of collective punishment, in the form of austerity measures in the Greek context. The sense of expressed guilt serves the individualistic, neoliberal view of the world, a view in which 
individuals each take responsibility for their "guilty" practices and jointly accept the punishment that comes through the austerity measures. Similar explanations favoring collective blaming that result in the need to change oneself and accept the austerity measures are echoed in both the US and the UK. In a widely read 2009 editorial, James Kelly, a past president of the National Association of Social Workers, USA, attributes the cause of the financial crisis to collective overspending, stating that he hopes that the "overwhelming number of challenges ... will ... perhaps push us to choose less wasteful lifestyles" (Kelly, 2009, cited in Coleman, 2012, p. 79). This statement endorses economic austerity by referring to the moral value of frugality. In the UK, the 2012 report of the Social Work Reform Board (2012), although not directly comparable to SKLE, appears to accept uncritically the last Coalition government's demand for 'efficiencies' and savings in deference to the collective approach. It is a view that ignores sound structural analysis and thereby poses a challenge to collective resistance, social justice and the social change values of social work. The moral arguments of this approach to austerity reinforce economic rationales of social spending cuts and other austerity measures showing no concerns of how best to meet human needs and advance the social well-being of society. This paper suggests this is prevalent even though contested with the leadership of a professional social work association.

\section{International relevance of austerity common sense phrases}

Similar austerity common sense phrases seem to be used elsewhere promoting similar politics of blame ((Monaghan, Flynn \& Power, 2013). The phrase/frame 'We ate them all together' bears also a striking resemblance to the 'We all partied' line used by the Irish finance minister, Brian Lenihan, to explain the Irish crisis and collectively blame all Irish people (Monaghan, Flynn \& Power, 2013; RTE One, 2010), as well as to the phrase 
'We must all share the pain', deployed by Gilmore, another previous Irish minister (Worker's Solidarity Movement, 2011). It also parallels the phrase used by Serbia's Prime Minister Aleksaner Vucie "The public sector, all of us actually, steal from the people we should serve..."(Vreme 2014 cited in Mikus, 2015, p. 211). In the UK, the previous Coalition government's sound bite "We are all in this together" seems to echo these sentiments (Conservative Party, 2010).

Moreover, across Europe ideological attacks on public sector workers (Mikus, 2015), welfare recipients and people living in poverty (Pantazis, 20016) are being intensified by the establishment. These, also promote politics of blame in a similar way to the Greek case presented and as such they can also be considered examples of austerity common sense.

There seems to be a strong moral tale of austerity underlying these ideas and phrases (Kelsey et al 2016) underlying strong moral categories of theft, collective blame, idleness and deserved punishment that aim to justify neoliberal policies as a redress to a supposedly immoral distribution of societal resources (Mikus, 2015). The power of these ideas gave rise to the scholarship of the cultural politics of austerity (Bramall, 2013) that seeks to address the ideological dimension of austerity rather than focusing predominantly on the economic processes (Pantazis, 2016; Bramall, 2013; Clarke \& Newman, 2012; Author's own, 2013). They demonstrate the "culturalization" of the crisis (Mylonas, 2012; 2014) and are part of a foundation of strategies for state retrenchment called by Clarke \& Newman (2012) an 'alchemy of austerity' through which the consent of populations is sought. They reflect the ideological reworking of the financial crisis of how to allocate blame and responsibility (Clarke \& Newman, 2012) obscuring the systemic causes of the crisis. 
Furthermore, in some western countries, such as the UK, Australia and Canada, the political elite is using the situation in Greece to promote its own neoliberal agenda of social spending cuts by asserting to its electoral base that "if you do not accept the social spending cuts we will end up like Greece" (Author's own). This image of Greece, as a country responsible for a self -inflicted catastrophe, is invoked in order to cause fear. Fear then can become an ideological control mechanism since when it is invoked it can legitimate the social and political policies of the powerful (Mullen, 2009).

Of course as it has been already discussed not everyone is passively accepting the dominant explanations of the causes of the austerity measures. There is a contested understanding both in the wider society in Greece and world-wide as reflected by progressive anti-austerity demonstrations organised by trade unions and in the good electoral performance of anti-austerity politicians such as Corbyn and Sanders in UK and USA respectively. Also, this contested understanding is seen clearly within SKLE.

The contested understanding within SKLE might reflect a historical tension within the social work profession world-wide. Since its inception, social work has navigated between an individualistic approach and understanding of social problems (micro level) and a structural approach and understanding of social problems (macro level). This micro and macro division corresponds to the two dominant strands of social work (Hugman, 2009). Traditionally, different segments of the social work profession have engaged in either supporting or challenging the status quo (to varying degrees) Ioakimidis, 2011; authors own). The dominant acceptance of the 'We ate them all' sentiment supports the status quo interpretation, which promotes the political elite's ideas as common sense. High-ranking members of SKLE's leadership seem to have internalised the dominant interpretation of the GPDC as self-evident and tried to impose this understanding on all members. The forceful ways in which this interpretation is advocated as a universal truth/conventional wisdom affirms the relevance of the application of the Gramscian 
concept of hegemony (Gramsci, 1971). The members who resisted this interpretation seem to be the ones who challenge the status quo. It will be worthwhile exploring in a future study the contributions these members make in participation in strikes and in activities such as the European wide social work meeting organized by SKLE in Athens (SKLE, 2016) to address austerity policies. It will also be worthwhile finding out how changes in the membership of SKLE's executive committee following the last SKLE elections may have changed SKLE's framing of austerity.

\section{Conclusion}

In this paper I introduce a preliminary conceptualization of austerity common sense in order to start the discussion of why austerity policies, despite the social harm they cause, have support not only from the economic and political establishment but also from members of the social work profession. Building on the Gramscian concept of common sense (1971), I argue that the continuing support can be explained partly through the concept of austerity common sense. Austerity common sense refers to the set of beliefs circulated by the ruling elite and adopted by some members of the leadership of the Greek Association of Social Workers (SKLE) as well as others within Greece and the European Union to understand austerity policies. But, at the same time, this research suggests that not all members endorse the dominant explanation, thus indicating that there is room for resistance. This argument seems to support Gill's (1995) position that the neoliberal austerity project is dominant but not totally hegemonic. According to Gramsci, change is made possible by the development of counter-hegemonic practices, which challenge the ruling class's interpretation of reality. In this paper the counterhegemonic practices are reflected in the narratives of the members who challenge the dominant explanation. The direction that the social profession may take has various possibilities, depending on the framing that will become dominant. If this counterhegemonic framing succeeds then the possibility of mounting a counterhegemonic attack 
alongside other progressive social organisations, parties and movements, might be possible.

It is recognised that the empirical evidence on which this paper is based is limited and the concept of austerity common sense requires further empirical analysis, however, future research endeavors using mixed research methods can help develop further the initial conceptualisation austerity common sense that has been attempted here-A challenge for the scholarly "research on ideas is to employ more statistical and quantitative methods" (Beland \& Cox, 2010:17). Despite the small scale of the research, this paper opens up the discussion on the contested nature of austerity measures within the social work profession which can be explored in future research. Furthermore, it offers the opportunity to interrogate the ideological meaning hiding behind words and phrases that can act to legitimise the austerity measures which cause immense social harm, not only to the social work profession but to the wider community. Discourses prioritising so called cultural or individual deficiencies are nothing new. However, they have re-emerged since the financial crisis in order to legitimise the imposition of austerity policies (Pantazis, 2016) and, as such, it is important to actively interrogate them, which this paper does. This study is part of the call of the critical tradition of social work about the necessity to engage in the understanding and interrogation of words and phrases within the socio-economic conditions from which they emerge, in order to unmask potential ideological meaning. Language is one of the key mediums that ideology is generated (authors own; Garrett, 2017). Ideas and words matter (Garrett, 2017; Authors own; Beland \& Cox, 2010) and this paper can contribute towards that understanding.

\section{References}


Author's_own_2013_2015_2016_2017a_2017b

Béland, D., \& Cox, R. H. (Eds.). (2010). Ideas and politics in social science research. Oxford University Press.

Bramall, R. (2013). The cultural politics of austerity: Past and present in austere times. Berlin: Springer.

Braun, V. \& Clarke, V. (2006). Using thematic analysis in psychology. Qualitative Research in Psychology, 3 (2), 77-101.

Clarke, J. \& Newman, J. (2012). The alchemy of austerity. Critical Social Policy, p.0261018312444405.

Coleman, S. (2012). The decimation of America's middle class and Its meaning for social work. Journal of Progressive Human Services, 23(1), 76-93.

Conservative Party (2010). 'David Cameron: We Must Tackle Britain's Massive Deficit and Growing debt' [speech]. Retrieved from http://www.conservatives.com/News/Speeches/2010/06/David_Cameron_We_must_t ackle_Britains_massive_deficit_and_growing_debt.aspx

Cooney, K. (2006). Mothers first, not work first: Listening to welfare clients in job training. Qualitative Social Work, 5(2), 217-235.

Cree, V. (1995). From Public Streets to Private Lives: The Changing Task of Social Work, Aldershot: Avebury.

Delta World (2012). Sarkozy Ensures that Settings are Necessary to Not End Up Like Greece and Spain. Retrieved from http://www.deltaworld.org/economy/Sarkozyensures-that-settings-are-necessary-to-not-end-up-like-Greece-and-Spain/ 
Dorling, D. (2014). Inequality and the 1\%. Verso Books.

Dymski, G. (2013). The logic and impossibility of austerity. Social Research: An International Quarterly, 80(3), 665-696.

ENET (2010, 25 September 2010). Pagkalos Against Civil Servants. Retrieved from http://www.enet.gr/?i=news.el.article\&id=206997

European Commission (2013a). Employment and Social Developments in Europe, 2013. Brussels: European Commission.

European Commission (2013b). Social Protection Budgets in the Crisis in the EU. Brussels: European Commission.

European Union (2014). Social Europe: Annual Report of the Social Protection Committee on the Social Situation in the European Union. Luxembourg: European Union.

Garrett, P. M. (2017). Welfare Words. Critical Social Work and Social Policy. London: Sage.

Garrett, P. M. (2008). Thinking with the Sardinian: Antonio Gramsci and Social Work. European Journal of Social Work, 1(3), 237-250.

Garrett, P. M. (2009). The "Whalebone" in the (Social Work) "Corset"? Notes on Antonio Gramsci and social work educators. Social Work Education, 28 (5), 461475. 
Gathmann, F. \& Medick, V. (2011). German Chancellor on the Offensive: Merkel Blasts Greece over Retirement Age, Vacation. Retrieved from http://www.spiegel.de/international/europe/0,1518,763294,00.html\#ref=nlint

Channel 4 (2011, 7 November). Go Greek for a Week Channel 4, UK. Retrieved from http://www.channel4.com/programmes/go-greek-for-a-week

Gill, S. (1995). Globalisation, market civilisation, and disciplinary neoliberalism. Millennium, 24(3), 399-423.

Gramsci, A. (1971). Selections from the Prison Notebooks of Antonio Gramsci. Translated from Italian and edited by Q. Hoare and G. N. Smith. Lawrence and Wishart: London.

Hall, S. and O'Shea, A. (2013). Common-sense neoliberalism. Soundings, 55(55), 9-25.

Harvey, D. (2005). A Brief History of Neoliberalism. Oxford: Oxford University Press.

Hermann, C. (2014a). Structural adjustment and neoliberal convergence in labour markets and welfare: The impact of the crisis and austerity measures on European Economic and Social Models. Competition and Change, 18(2), 111-130.

Hermann, C. (2014b). Crisis, structural reform and the dismantling of the European Social Model(s). Economic and Industrial Democracy, 1-18, DOI: 10.1177/0143831X14555708.

Ioakimidis, V. (2011). Expanding imperialism, exporting expertise: International social work and the Greek project, 1946-1974. International Social Work, 54(4), 505-519.

Ioakimidis, V. and Teloni, D.D., (2013). Greek social work and the never-ending crisis of the welfare state. Critical and Radical Social Work, 1(1), 31-49.

Ives, P. (2004). Language and Hegemony in Gramsci. London: Pluto Press. 
Kamberelis, G., Dimitriadis, G. (2013). Focus Groups, London: New York.

Karamesini, M. (2014) Structural crisis and adjustment in Greece: social regression and the challenge to gender equality, 165-185, in Karamessini M. and Rubery, J. (eds.) Women and Austerity: The Economic Crisis and the Future for Gender Equality, New York: Routledge.

Kelsey, D., Mueller, F., Whittle, A., \& KhosraviNik, M. (2016). Financial crisis and austerity: Interdisciplinary concerns in critical discourse studies. Critical Discourse Studies, 13(1), 1-19.

Lorenz, W. (2005) Social work and new social order: Challenging neo-liberalism's erosion of solidarity. Social Work and Society, 3(1), 93-101.

Landon, T. (2011, 8 November 2011). 'A Greek Political Scion Undone by Economics'. The New York Times. Retrieved from http://www.nytimes.com/2011/11/08/world/europe/prime-minister-georgepapandreou-of-greece-undone-by-economics.html

Lankford, J. (2012). 'Greece a Good Example of Crisis Coming to U.S.' 'Editor's Pick' in Fox Business. Retrieved from http://video.foxbusiness.com/v/1450125216001/greece-a-good-example-of-crisiscoming-to-us/

MacKinnon, S. (2009). Social work intellectuals in the Twenty-First Century: Critical social theory, critical social work and public engagement. Social Work Education, 28(5), 512-527.

Mikuš, M. (2015). The justice of neoliberalism: moral ideology and redistributive politics 
of public-sector retrenchment in Serbia. Social Anthropology, 24 (2), 211-227 .

Mullen, A. (2009). The propaganda model after 20 Years: Interview with Edward Herman and Noam Chomsky. Westminster Papers in Communication and Culture, $6(2), 12-22$.

Mylonas, Y. (2014). Crisis, austerity and opposition in mainstream media discourses of Greece. Critical Discourse Studies, 11(3), 305-321.

NEA (2010). Pagkalos: “The Jackasses and Lazy People Who Enter Civil Service Remain Jackasses and Lazy for a Whole Life" O kopritis poy mpainei sto dhmosio paramenei kopritis mia zoi”. Retrieved from http://www.tanea.gr/ellada/article/?aid=4611135

OECD (2010). Corporate Income Tax Rate/Corporate and Capital Income Taxes. OECD TAX Data Base. Retrieved from

http://www.oecd.org/document/60/0,2340,en_2825_293564_1942460_1_1_1_1,00.ht ml\#C_CorporateCaptial.

OECD (2014). Society at a Glance. The Crisis and its Aftermath. Paris: OECD.

OECD (2015). In It Together: Why Less Inequality Benefits All. Paris: OECD.

Pantazis, C. (2016). Policies and discourses of poverty during a time of recession and austerity. Critical Social Policy, 36(1), 3-20.

Preston, P. \& Silke, H. (2011). Market'realities': De-coding neoliberal ideology and media discourses. Australian Journal of Communication, 38(3), 47. 
RTE One (2010, 24 November 2010). 'Brian Lenihan "We All Partied” on Prime Time'. Retrieved from http://www.youtube.com/watch?v=YK7w6fXoYxo.

Salomon, M. (2015) Of austerity, human rights and international institutions. European Law Journal 21,(4): 521-545.

Schui, F. (2014). Austerity: The great failure. New Haven, CT: Yale University Press.

Singh, G. \& Cowden, S. (2009) The Social worker as intellectual. European Journal of Social Work, 12(4), 1369-1457.

SKLE (2016) European meeting of social workers against austerity. https://skle.gr/index.php/el/2015-01-27-08-52-05/drasi/item/544-panevropaikisynantisi-ergasias-koinonikon-leitourgon-gia-tin-politiki-tis-litotitas-athina-21-kai-22ianouariou-2016

Social Work Reform Board (2012). 'Building a Safe and Confident Future: Maintaining Momentum - A Progress Report from the Social Work Reform Board' Retrieved from https://www.education.gov.uk/publications/eOrderingDownload/SWRB\%20progress \%20report\%20-\%20June\%202012.pdf

Spiegel (2009). 'Siemens Bribery Scandal in Greece'. Retrieved from http://www.spiegel.de/international/business/siemens-bribery-scandal-in-greece-exboss-could-help-shed-light-on-corruption-a-633198.html

Stiglitz, J. E. (2002). Globalization and Its Discontents, New York: W.W. Norton.

Wallace, J. \& Pease, B (2011). Neoliberalism and Australian social work:

Accommodation or resistance? Journal of Social Work, 11(2), 132-142.

Wilkinson, R. \& Pickett, K. (2009). The Spirit Level (Why More Equal Societies Almost Always Do Better). London: Allen Lane. 
Workers Solidarity Movement (2011). Rich and Poor Must Share the Pain Says Gilmore. Retrieved from http://www.wsm.ie/c/rich-poor-share-pain-gilmore.

Žižek, S. (2009). First As Tragedy, Then As Farce. London: Verso. 